\title{
THE ROLE OF MORPHOLOGICAL AWARENESS AND EXPLICIT MORPHOLOGICAL INSTRUCTIONS IN ELT
}

\author{
Isvanelly Anwar, Rusdi Noor Rosa \\ English Department, Faculty of Languages and Arts \\ Universitas Negeri Padang, Padang, Indonesia \\ E-mail: isva1982@gmail.com
}

Received: 20 October 2019

Accepted: 24 April 2020

\begin{abstract}
As a branch of linguistics, the role of morphology in learning English should not be taken carelessly. As the study of internal structure of words, morphology provides a lot of knowledge necessary to develop students' English proficiency. However, many English teachers are still not aware of its important role in successful and effective learning process because they tend to be busy searching for media, strategies or techniques which they consider effective in teaching. In relation to the importance of morphology in English language teaching (ELT), this paper aims at explaining the important role of morphological awareness and instructions in teaching English as a foreign language to junior high schools in Indonesia. This is a descriptive study using literature review as the method. The data were secondary data in the form of documents including articles, journals and books. The data were analyzed using a content analysis by reading and reviewing the documents. The results of the data analysis show the significant role of morphological awareness and morphological instructions in facilitating the students at junior high school to learn English more easily, with significantly greater achievement. It is, therefore, concluded that students with morphological awareness or students that are treated by using morphological instruction gain better achievements in their English learning, resulting in their better English proficiency.
\end{abstract}

Keywords: morphological awareness, morphological instruction, role of morphology, teaching English as a foreign language

\section{Introduction}

Learning to spell English words is a critical aspect in the development stages of learning English as a foreign language, especially for Indonesian learners. The consideration of such importance can be seen in a number of studies focusing on learning to spell English words in Indonesia. However, most of the studies related to learning to spell were done without involvement of linguistic theories; instead, they tended to focus on seeking for several techniques best applicable to teach spelling, such as word olympics game (Surtini, 2014), spelling bee game (Rohmawati, 2015), crossword puzzles (Diniyati, 2009), concentration game and tell a story game (Nurhayati, 2012), and so forth. The main weakness of learning to spell without the involvement of linguistic theories is that the learners' spelling ability will only be limited to the English words that have been taught to them, and they will have difficulties to spell English words that have never been taught to them. 
The linguistics theory best applicable to teach how to spell English words is morphology, the study of word structure. Various scholars have found that teaching students explicitly about the morphological relationships between words improves the students' spelling ability, which eventually improves their reading and writing skills (Bowers, Kirby, \& Deacon, 2010; Hurry, Nunes, Bryant, Pretzlik, Parker, Curno \& Midgely, 2010; Schano, 2015). Especially for junior high school students in Indonesia, teaching morphology explicitly is very helpful in building their knowledge and ability of English spelling because this is the first level they learn English formally (at school). In the latest curriculum of national education for junior high school, the 2013 curriculum (Ministry of Education and Culture, 2013), it is mentioned that teaching English at junior high schools is aimed at preparing the students to be able to communicate in English both in oral and written form. It is undeniable that spelling has an important role in achieving such national curriculum objectives: students' ability in oral and written English communication. In addition, this statement obviously supports the role of teaching morphology explicitly to junior high school students. However, it is rare to find English teachers at junior high schools in Indonesia who teach morphology explicitly in the classroom.

In addition, the problem of the absence of explicit morphology instructions in teaching English spelling at junior high schools in Indonesia is caused by the absence of morphological awareness among the students. This may be caused by teachers who do not develop their students' morphological awareness. In fact, morphological awareness in English, according to Kuo and Anderson (2006) becomes an increasingly important predictor of reading ability. Besides, they also recommend that morphological mindfulness is interlaced with different parts of metalinguistic mindfulness and etymological capability, particularly phonological mindfulness, syntactic mindfulness, and vocabulary information.

In relation to the problem of morphological awareness and explicit morphological instruction in English learning, this paper aims at describing their advantages to facilitate junior high school students in Indonesia to learn English more easily and more effectively.

\section{Literature Review}

\subsection{Morphological Awareness}

Morphological awareness is related to the awareness of morphological elements (morphemes) in a larger structure (i.e. phrase or sentence). Morpheme, as the smallest meaningful language unit (Katamba \& Stonham, 2006; Rosa, 2013), plays an important role in building the language meaning in a larger structure (Carlisle, 2000; Deacon et al., 2009). It is, therefore, simply asserted that morphological awareness is the awareness of the existence and the role of the smallest meaningful unit in language (Apel, 2014).

In addition to awareness, the understanding of morphological awareness also includes the term "ability" as mentioned in several literatures (Kuo \& Anderson, 2006; Tong et al., 2011; Kirby et al., 2012; Deacon et al., 2013). Kirby et al. (2012: 389), for example, define morphological awareness as the conscious awareness of the morphemic structure of words and the ability to reflect on and manipulate that structure. In almost similar tone, Deacon et al. (2013: 1113) define morphological awareness as the awareness of and the ability to manipulate morphemes in the oral language.

The definitions of morphological awareness elaborated in the previous paragraphs imply its important role in language learning, particularly in learning a foreign language.

\subsection{Explicit Morphological Instructions}


Explicit instruction becomes one of the recent popular language teaching approaches. This is particularly helpful to facilitate misconception in understanding and applying Communicative Language Teaching (CLT) in classroom. Badawi (2019) argues that many EFL teachers and material developers have misunderstood or misused CLT, suggesting the inclusion of language form instruction in teaching. In fact, a number of studies have proved that explicit instruction has shown promising results in foreign language learning (e.g. Shippen et al., 2005; Graves et al., 2011; Wiley, 2015).

One of the suggested explicit language form instructions is morphological instruction. Following the concept of explicit instruction elaborated above and its relation to language teaching, explicit morphological instruction can be defined as explicitly explaining morphology lessons to students in language teaching (Wiley, 2015). In a more comprehensive definition, explicit morphology instruction is a teaching strategy that allows the teacher to demonstrate inflectional and derivational morphemes as target learning items of the suggested program in a direct way (Badawi, 2019: 168).

\section{Research Method}

This is a descriptive study using literature review as the method. The data were secondary data in the form of documents, including articles, journals and books. The data were collected through reading and reviewing such documents. The data were then analyzed using a content analysis. In analyzing the data, as suggested by Nilamsari (2014), four main steps were carried out: (i) collecting the literature concerning morphological awareness and morphological instructions in teaching English; (ii) reducing the data by analyzing the advantages of morphological awareness and morphological instructions in teaching English; (iii) identifying the role of morphological awareness and the necessities of applying morphological instructions in teaching English as a foreign language to junior high school students in Indonesia; and (4) drawing conclusions about the important role of morphological instructions in teaching English to junior high school students objectively and systematically.

\section{Results and Discussion}

Teaching English as a foreign language to junior high school students in Indonesia should be started by making them realize the role of spelling in developing their English ability. Such effort helps teachers to develop the students' awareness of the role of morphology in learning English. Developing an awareness of English morphology will enable language teachers to help their learners understand how words enter a language, what they consist of and how they are formed by combining prefixes, suffixes, and roots $(\mathrm{Oz}, 2014: 83)$. Recent research suggests that learners with an awareness of word-formation processes tend to have larger vocabulary and better reading comprehension (Kieffer \& Lesaux, 2008; Kieffer \& Lesaux, 2012), and by extension better writing (Templeton, 2012). In addition, CoutuFleury (2015) has also examined that morphological awareness training has an impact on the reading and spelling abilities of young dyslexic students, those with inaccurate or slow printed word recognition and poor spelling problems which affect their reading fluency, comprehension and written expression (Moats, Carreker, Davis, Meisel, Spear-Swerling, \& Wilson, 2010). This finding implies that if students with such disabilities can improve their reading and spelling through morphological awareness, normal students should be able to achieve more than them. Consequently, morphology can be a valuable instructional tool for language learners at junior high schools in Indonesia to develop and use vocabulary 
creatively. The role of vocabulary in the efforts of English language mastery is also undeniable because it is impossible for the students to communicate in English without an adequate amount of vocabulary.

Not only does morphological awareness benefit reading and writing, it also benefits listening. One of its benefits to listening skill is mentioned in the study done by Saeidi and Mirzapour (2013) who investigated the relationship between morphological awareness and listening comprehension ability in Iranian EFL learners. They took a total of 40 students (25 females and 15 males) majoring in English Language Teaching (ELT) at Hamedan Branch, Islamic Azad University as the participants who were randomly divided into two groups of 20 participants, Control and Experimental groups. Four short listening passages were used as the pre-test which included 30 tokens of words with morphemic structures. Then four one hour sessions were held for the experimental group. After four sessions, four short listening passages were used as the post-test. The obtained result indicated relationship between morphological awareness and listening comprehension ability.

After developing their awareness of English morphology, then they are taught morphology explicitly in the classroom. In terms of its procedure, Coutu-Fleury (2015) proposes three ways of teaching English morphology explicitly in the classroom: (i) showing the non-correspondence between sound and spelling in English; (ii) showing inflectional and derivational morphemes in English; and (iii) demonstrating derivational morphemes triggering phonological changes in English.

The following is the example of showing the non-correspondence between sound and spelling in English.

a. heal /hil/ healthy /helӨi/

b. sane/sen/ sanity/sænıti/

The two examples show that the same letter or letter combination can be pronounced in different ways. However, the lack of exact correspondence between sound and spelling in these examples is not arbitrary. In many cases, the similar spelling captures the fact that these word pairs are morphologically related. Many of the spelling "irregularities" found in English can be explained through morphological relatedness. Although it is not always the case that morphologically related words are similarly spelled (e.g. profound - profundity), English is better viewed as having morphophonemic spelling system than a purely phonemic one. This suggests that morphological awareness also plays some role in learning the written system of English Coutu-Fleury (2015: 74).

Morphological awareness refers to the conscious knowledge of the word formation patterns in a language (Casalis, Cole, \& Sopo, 2004). This knowledge is based on the morphemes, including prefixes and both derivational and inflectional suffixes. The knowledge of derivational and inflectional suffixes is then becoming the second way of teaching morphology explicitly in ELT as illustrated below.

a. Inflectional Morphemes

$\begin{array}{lll}\text { 3rd person singular -s } & \text { plans = plan }+\mathrm{s} & \text { works = work + s } \\ \text { progressive -ing } & \text { planning = plan }+ \text { ing } & \text { working = work + ing } \\ \text { regular past tense -ed } & \text { planned = plan + ed } & \text { worked = work + ed } \\ \text { plural -s } & \text { books = book }+\mathrm{s} & \text { chairs = chair }+\mathrm{s}\end{array}$

b. Derivational Morphemes

$\begin{array}{lll}\text {-ment } & \text { statement }=\text { state }+ \text { ment } & \text { agreement }=\text { agree }+ \text { ment } \\ \text {-ful } & \text { powerful }=\text { power }+ \text { ful } & \text { joyful }=\text { joy }+ \text { ful } \\ \text {-en } & \text { strengthen = strength + en } & \text { deepen = deep }+ \text { en }\end{array}$




$$
\text { -ly slowly = slow }+ \text { ly rapidly = rapid }+ \text { ly }
$$

The examples above can only be understood through morphological awareness that allows students to realize that books is composed of two pieces of meaning, i.e. book and the plural marker -s. Furthermore, it allows students to see the meaning consistency in regular plurals, such as in chairs, computers, desks, and so forth. This is particularly important to junior high school students because a plural marker in bahasa Indonesia, i.e. through reduplication, is quite different from English. Moreover, in English, inflected forms are more common than derived forms and more consistent in their semantics; they play an important role in grammar and they are generally learned earlier (Rosa, 2013). In English, derived forms are later acquired and considered harder, partly because of their more complex semantics and partly because derivational suffixes often trigger complex and seemingly arbitrary phonological changes (Coutu-Fleury, 2015). The examples of English derivational morphology causing sound changes can be seen below.

-ity sanity /sanıti/ < sane /sen/ + ity

-ic sarcastic /səıkǽstik/ < sarcasm /sáıkoezəm/ + ic

-ify solidify /səlídəfai/ < solid /sálıd/ + ify

-ous gracious /gıejás/ < grace /gıes/ + -ous

Such sound changes are cuased by the use of primary affixes (Katamba, 1993). In addition to primary affixes, Katamba (1993) also introduces secondary affixes, those which do not give sound or phonological changes in the derived word, such as -ness and -ly.

Unlike Coutu-Fleury (2015) that focuses on teaching procedure, Griva and Anastasiou (2009) introduce a morphological-related teaching approach, which is named Morphological Processing Spelling Approach (MPSA). MPSA is a type of morphological processing strategies training included in the spelling program. MPSA provides explicit and systematic metamorphological instruction in word-level skills, when students do dictation from a meaningful text. By drawing students' attention to the inflectional and derivational morphology, the principal aim of the MPSA is to help students, especially the poor ones, develop morphological knowledge and morphological strategies through the spelling process (Griva \& Anastasiou, 2009: 202).

In order to examine how significant the contribution of morphological awareness is to English language learning, scholars use different instruments. Khoshkhoonejad, Khalifelu, and Abdipour (2016), for example, use three instruments to find out the effect of morphological awareness on vocabulary learning among Iranian secondary school students: proficiency test, morphological relatedness test, and morphological structure test. The results of this study are very important to be promoted and applied (if possible) in Indonesian junior high school because both Iran and Indonesia consider English as a foreign language. Their research shows that morphological awareness is an important tool in improving the English proficiency of Iranian secondary school students, especially in terms of their vocabulary mastery. The results of data analysis show that the experimental group outperforms the control group after being exposed to the morphological strategies (Khoshkhoonejad et al., 2016: 156).

Furthermore, Tabatabaei and Yakhabi (2011) use Iranian Nation's Vocabulary Level Test (VLT) as the instrument to determine the relationship between morphological awareness and vocabulary size of EFL learners. They collect the data from Iranian high school students through random sampling. The VLT is used to test students' knowledge of words drawn from the 2000, 3000 and 5000 most frequent occurring word families. Two morphological awareness tasks (a morpheme identification task and a morphological 
structure test) are also used to assess students' morphological awareness. The VLT results indicate that the students perform better at the 2000 level than the two higher frequency levels. There exists a significant relationship between the learners' performance on the vocabulary level test and the morphological awareness tasks. These findings implicate the importance of facilitating the students' morphological awareness in English vocabulary learning for EFL learners in Iran.

Furthermore, Goodwin, Gilbert \& Cho (2013) use three measures or instruments to examine the effect of morphological awareness to English mastery. The instruments used in their study are Reader-by-Word Measures, Derived-Word Reading Accuracy (DERIVED), and Root-Word Reading Accuracy (ROOT). These instruments examine the effects of morphological awareness on word reading among adolescents, looking into learner characteristics and their word reading ability. The study is carried out on 221 young middle school students enrolled in two suburban middle schools in the United States. The results show that the participants' performance at reading a particular root word described their skill of associating words of the same root. For instance, the participants are able to associate the word 'predict' with 'prediction'. This points to the fact that knowledge of morphology promoted learners' vocabulary skill where they are able to relate and derive meanings of the words that have the same root. They conclude that the learners' skills, morphemic awareness and knowledge of vocabulary, substantially promote word reading ability and hone their morphological skills. It is highly important for learners to be equipped with word reading skills and morphological awareness as they encounter more academically specific vocabulary in school textbooks which are mostly morphologically-complex in nature. Even though this study is conducted in an English speaking country, USA, the results of this study also strengthen the role of morphological awareness in English language learning because it is not only applicable in non-English speaking countries, but also in English speaking countries.

Other scholars, Gilbert, Goodwin, Compton, and Kearns (2013) who conduct a study to evaluate the effects of morphological analysis of multisyllabic words on reading comprehension among 169 fifth graders from 40 schools even use five instruments in their study: (i) Academic Knowledge subtest of Woodcock-Johnson III, (ii) Morphological Awareness test, (iii) Multisyllabic Word Reading test, (iv) Reading Comprehension assessment, and ( $v$ ) The Peabody Picture Vocabulary test. The findings of their study show that the relationship between word reading and morphemic analysis was instrumental in yielding positive result in reading comprehension. A major difference is noted on the effect of morphological awareness, where 39 percent of the participants encounter more problems reading morphologically-complex words compared to the rest of the subjects who are at a higher level of proficiency. This study also indicates that the relationship between morphological analysis and reading comprehension is mediated by ability in reading multisyllabic words. Morphological awareness is found to have an important association with reading comprehension particularly for weaker readers.

In addition to morphological awareness, explicit morphological instruction also plays a significant role in advancing junior high school students' English mastery. Nunes and Bryant (2006) provide experimental evidence that morphological instruction improves word reading and spelling, but they also acknowledge that this type of instruction is rare in schools. This omission may have particular relevance for literacy development in English due to the particular nature of oral and written morphology in English. Similarly, Carlisle (2007) also 
found the effects of explicit instruction about morphology in teaching English in the classroom.

Besides, Bowers and Kirby (2009) use Peabody Picture Vocabulary Test III (PPVT-III) as the instrument in examining the effect of morphological instruction to students' English proficiency. They conduct a study to examine the effects of morphological instruction on vocabulary acquisition. The participants were 81 children in two Grade 4 classes and two Grade 5 classes from two public Catholic schools in and around the area of Kingston, Ontario. All participants were administered the Peabody Picture Vocabulary Test III (PPVTIII), a test of receptive vocabulary knowledge. They conclude that the treatment group makes better use of pre-test vocabulary knowledge in learning new vocabulary. The results are discussed in light of the growing debate regarding whether to teach many words in a shallow way or to provide deep, rich instruction about fewer words.

The results of the study conducted by Brynt (2006), Carlisle (2007) and Bowers and Kirby (2009) are appropriate to become the key reason of applying explicit morphology teaching to junior high school students in Indonesia since the teaching morphology explicitly to junior high school students in Indonesia is rare. Besides, the results of the study conducted by Gilbert et al. (2013) describes the learning habit among Indonesian students since a large number of studies shows that most of Indonesian students have weakness in reading English texts. As a matter of fact, their low reading habit needs to be improved if they want to get good achievement in learning English. In addition, their good background of reading ability will help them a lot to prepare to go to higher level of education. This also indicates that morphological awareness is effective to be developed and morphological instruction is effective to be explicitly taught to junior high school students in Indonesia.

Teaching is one of the application of linguistics as the scientific study of language because there will be no teaching without the use of language. Therefore, it is worth considering to explicitly apply the linguistic theories in teaching English to junior high school students, especially theories related to morphology. The basic unit of language that allows students to use English actively is word or vocabulary, which is the core discussion in morphology as it is defined as the study of the internal structure of words and the rules governing the formation of words in a language (Oz, 2014:. 83).

The results of this study proposes a model of teaching English at junior high schools in Indonesia by applying phonological awareness and explicit morphological instructions as shown in Figure 1.

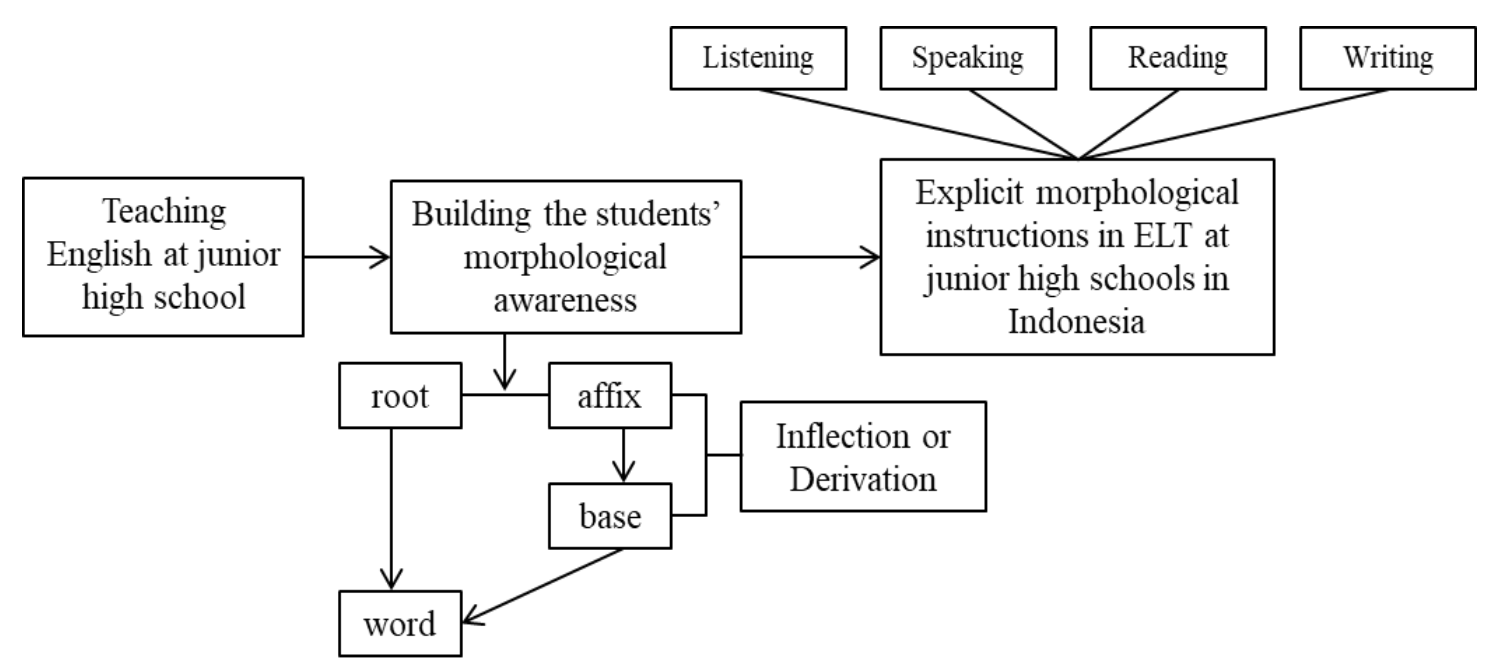

Figure 1 Morphological awareness and explicit morphological instructions in ELT 
The model presented in Figure 1 shows that teaching English at junior high school in Indonesia should begin by building the students' morphological awareness by introducing them to both free morphemes (roots) and bound morphemes (affixes). In addition to words consisting of root, they should also be introduced to the words form through inflectional or derivational processes. These morphological processes should be explicitly taught to the students. These explicit morphological instructions are applied in teaching all of the English basic skills including listening, speaking, reading, and writing.

\section{Conclusions and Suggestions}

Based on the discussion elaborated in the previous section, it is concluded that morphological awareness of the junior high school students is completely necessary to be developed because it does not only facilitate the students in learning English more easily, but it also helps teachers in teaching English more effectively. Various studies done by English teaching scholars have proved that students with morphological awareness or students that are treated by using morphological instruction gain better achievements in their English learning, resulting in their better English proficiency.

Therefore, it is suggested for English teachers, especially to those who teach English at junior high school to use morphological instructions in learning process, or to teach morphology explicitly to their students. In addition, it is also suggested to use more varied instruments to test the effectiveness of morphological instructions in facilitating the students at junior high school to learn English more easily.

\section{References}

Apel, K. (2014). A comprehensive definition of morphological awareness: Implications for assessment. Top Lang Disorders, 34(3), 197-209.

Badawi, M. F. A. (2019). The effect of explicit English morphology instruction on EFL secondary school students' morphological awareness and reading comprehension. English Language Teaching, 12(4), 166-178.

Bowers, P. N. \& Kirby, J. R. (2009). Effects of morphological instruction on vocabulary acquisition. Reading and Writing, 23(5), 515-537

Bowers, P. N., Kirby, J. R., \& Deacon, S. H. (2010). The effects of morphological instruction on literacy skills: A systematic review of the literature. Review of Educational Research, 80, 144-179.

Carlisle, J. F. (2000). Awareness of the structure and meaning of morphologically complex words: Impact on reading. Reading and Writing: An Interdisciplinary Journal, 12, 169190.

Carlisle, J. F. (2007). Fostering morphological processing, vocabulary development, and reading comprehension. In R. K. Wagner, A. E. Muse, \& K. R. Tannenbaum (Eds.), Vocabulary acquisition: Implications for reading comprehension (pp. 78-103). New York: Guilford Press.

Casalis, S., Colé, P., \& Sopo, D. (2004) Morphological awareness in developmental dyslexia. Annals of Dyslexia, 54(1), 114-138.

Coutu-Fleury, C. (2015). The effects of morphological awareness training on the reading and spelling performance of young dyslexics. Langues et Linguistique, 35, 72-79.

Deacon, S. H., Benere, J., \& Pasquarella, A. (2013). Reciprocal relationship: Children's morphological awareness and their reading accuracy across grades 2 to 3 . Developmental Psychology, 49, 1113-1126. 
Deacon, S. H., Kirby, J. R., \& Casselman-Bell, M. (2009). How robust is the contribution of morphological awareness to general spelling outcomes? Reading Psychology, 30, 301-318.

Diniyati, N. The use of crossword puzzles to improve students' spelling (An action research of fourth grade students of SDN Cokro, Grabag Kabupaten Magelang in the Academic Year of 2008/2009). Unpublished Thesis. Semarang: Universitas Negeri Semarang.

Gilbert, J. K., Goodwin, A. P., Compton, D. L., \& Kearns, D. M. (2013). Multisyllabic word reading as a moderator of morphological awareness and reading comprehension. Journal of Learning Disabilities, 47(1), 34-43.

Goodwin, A. P., Gilbert, J. K., \& Cho, S. J. (2013). Morphological contributions to adolescent word reading: An item response approach. Reading Research Quarterly, 48(1), 39-60.

Graves, A.W., Brandon, R., Duesbery, L., McIntosh, A., \& Pyle, N.B. (2011). The effects of tier 2 literacy instruction in sixth grade: Toward the development of a response-tointervention model in middle school. Learning Disability Quarterly, 34(1), 73-86.

Griva, E., \& Anastasiou, D. (2009). Morphological strategies training: The effectiveness and feasibility of morphological strategies training for students of English as a foreign language with and without spelling difficulties. Journal of Writing Research, 1(3), 199223.

Hurry, J., Nunes, T., Bryant, P., Pretzlik, U., Parker, M., Curno, T., \& Midgely, L. (2010). Transforming research on morphology into teacher practice. In G. Cook \& S. North (Eds.), Applied linguistics in action: A reader (pp. 160-170). London: Routledge.

Katamba, F. (1993). Morphology. London: Macmillan Press Ltd.

Katamba, F. \& Stonham, J. (2006). Morphology. $2^{\text {nd }}$ Edition. London: Palgrave Macmillan.

Khoshkhoonejad, A., Khalifelu, S. F., \& Abdipour, S. (2016). Exploring the Effect of Morphological Instruction on Vocabulary Learning among Iranian EFL Learners. Journal of Education and Learning. 10(2), 151-158.

Kieffer, M. J., \& Lesaux, N. K. (2012). Development of morphological awareness and vocabulary knowledge in Spanish-speaking language minority learners: A parallel process latent growth curve model. Applied Psycholinguistics, 33, 23- 54.

Kirby, J. R., Deacon, S. H., Bowers, P. N., Izenberg, L., Wade-Woolley, L., \& Parrila, R. (2012). Children's morphological awareness and reading ability. Reading and Writing: An Interdisciplinary Journal, 25, 389-410.

Kuo, L. \& Anderson, R. C. (2006). Morphological awareness and learning to read: A cross language perspective. Educational Psychologist, 41, 161-180.

Moats, L., Carreker, S., Davis, R., Meisel, P., Spear-Swerling, P. M. L., \& Wilson, B., (2010). Knowledge and practice standards for teachers of reading. Baltimore, MD: The International Dyslexia Association: Professional Standards and Practice Committee.

Nilamsari, N. (2014). Memahami studi dokumen dalam penelitian kualitatif. Wacana, XIII(2), 177-81.

Nunes, T., \& Bryant, P. (2006). Improving literacy by teaching morphemes. New York: Routlege.

Nurhayati, D. A. W. (2012). Improving students' English spelling ability through concentration game and tell a story game. Proceedings of The 2nd National Conference on Teaching English for Young Learners, pp. 205-217.

$\mathrm{Oz}, \mathrm{H}$. (2014). Morphology and implications for English language teaching. In A. Saricoban (Ed.), Linguistics for English language teaching studies (pp. 83-120). Ankara: Ani Publishing. 
Rohmawati, A. (2015). Spelling bee in teaching vocabulary. Journal of English and Education, $3(2), 1-15$.

Rosa, R. N. (2013). Introduction to linguistics. Padang: Sukabina Press.

Saeidi, M. \& Mirzapour, F. (2013). The impact of morphological awareness on Iranian university students' listening comprehension ability. International Journal of Applied Linguistics \& English Literature, 2(3), 69-74.

Schano, L. (2015). The influence of morphological knowledge on L2 reading comprehension. Langues et Linguistique, 35, 64-71.

Shippen, M. E., Houchins, D. E., Steventon, C., \& Sartor, D. (2005). A comparison of two direct instruction-reading programs for urban middle school students. Remedial and Special Education, 26(3), 175-182.

Surtini. (2014). Improving students' English word spelling ability by using word olympics game. Research Paper. Pontianak: Tanjungpura University.

Tabatabaei, O. \& Yakhabi, M. (2011). The relationship between morphological awareness and vocabulary size of EFL learners. English Language Teaching, 4(4), 262-273.

Templeton, S. (2012). Teaching and learning morphology: A reflection on generative vocabulary instruction. Journal of Education, 192(2/3), 101-107.

Tong, X., Deacon, S. H., Kirby, J. R., Cain, K., \& Parrila, R. (2011). Morphological awareness: A key to understanding poor reading comprehension in English. Journal of Educational Psychology, 103, 523-534.

Wiley, L. S. (2015). The effects of explicit morphology instruction on vocabulary skills in four struggling middle school readers. Master's Theses, Capstones, and Projects. Milwaukee: Cardinal Stritch University. 